\title{
Primary Cerebellopontine Angle Melanoma: A Case Report and Review
}

\section{Primer Serebellopontin Aç Melanomu: Bir Olgu Sunumu ve Derleme}

\author{
Laxminarayan BHANDARI ${ }^{1}$, Jacob ALAPATT ${ }^{2}$, Aparna GOVINDAN ${ }^{3}$, Thevar SREEKUMAR ${ }^{2}$ \\ ${ }^{1}$ Calicut Medical College, Department of General Surgery, Calicut, India \\ ${ }^{2}$ Calicut Medical College, Department of Neurosurgery, Calicut, India \\ ${ }^{3}$ Calicut Medical College, Department of Pathology, Calicut, India
}

Correspondence address: Laxminarayan BHANDARI / E-mail: lax321@gmail.com

\begin{abstract}
Primary melanomas at the cerebellopontine (CP) angle are extremely rare and considered a diagnostic dilemma. With only 16 prior cases reported so far, there is not enough material in world literature. We report a 29-year-old male who presented with vertigo, headache and features of lower cranial nerve involvement with MRI revealing a melanotic lesion at CP angle. The patient underwent right suboccipital craniectomy and only subtotal excision of the tumor was possible. Histopathologically it turned out to be malignant melanoma. Since a thorough search for any possible primary was futile, it was considered a primary melanoma. Patient was given adjuvant radiotherapy. Ten months later, he presented with weakness and multiple spinal metastases and two months later he succumbed to his disease. We did a comprehensive review of literature about various melanocytic tumors at the CP angle. Pathologically, melanocytic tumors range from benign melanocytomas to malignant melanoma with variable prognosis. The clinical presentation depends upon whether the lesions are diffuse or discrete. Surgery is the primary modality of treatment and the amount of tumor excised is related to the prognosis. We conclude the discussion with a novel classification for melanotic tumors of CNS and the current diagnostic pathway for a melanotic lesion at the CP angle.
\end{abstract}

KEYWORDS: Cerebellopontine angle melanoma, Intracranial melanoma, Primary melanoma

öz

Serebellopontin (CP) açıda primer melanomlar çok nadirdir ve tanısal bir ikilem olarak değerlendirilir. Şu ana kadar sadece 16 vaka bildirilmiştir ve henüz dünya literatüründe yeterli bilgi yoktur. Baş dönmesi, başağrısı ve alt kraniyal sinir tutulumu bulguları ile gelen ve MRG'nin CP açıda bir melanotik lezyon gösterdiği 29 yaşında bir erkek hasta sunuyoruz. Hastaya sağ suboksipital kraniektomi yapıldı ve tümör ancak subtotal olarak eksize edilebildi. Histopatolojik olarak malign melanom olduğu saptandı. Herhangi bir olası primer açısından kapsamlı bir araştırma yapmak anlamsız olduğundan primer melanom kabul edildi. Hastaya adjuvan radyoterapi verildi. Hasta on ay sonra zayıflık ve çok sayıda spinal metastaz ile geldi ve iki ay sonra hastalığı nedeniyle öldü. CP açıda çeşitli melanostik tümörler hakkında literatürü kapsamlı olarak araştırdık. Patolojik olarak melanostik tümörler benign melanositomlardan değişken prognozlu malign melanoma kadar değişmektedir. Klinik sunum lezyonların difüz veya tek tek olmasına göre değişir. Cerrahi temel tedavi modalitesidir ve eksize edilen tümör miktarı prognozla ilişkilidir. Tartışmayı MSS melanotik tümörleri için yeni bir sınıflandırma ve CP açıda bir melanotik lezyon için mevcut diagnostik yaklaşımı sunarak bitiriyoruz.

ANAHTAR SÖZCÜKLER: Serebellopontin açı melanomu, İntrakraniyal melanom, Primer melanom

\section{INTRODUCTION}

Primary melanocytic tumors of the CNS are rare and have an estimated incidence of 0.9 per 10 million (13). They vary from benign to malignant. Virchow described the first case of primary diffuse intracranial melanoma in 1859 and Oogle $(2,14)$ reported the first case of primary intracranial solitary melanoma in 1899. Since then, there have been only 250 cases of primary intracranial melanoma reported by WHO (8). The common sites for a primary CNS melanoma are, lobar (53.1\%), posterior fossa (17.3\%) and pineal region (13.6\%) (2). Primary melanoma of the cerebellopontine angle is very rare and was first described in 1948 by Bailey (2). There are only seventeen $\mathrm{CP}$ angle melanoma cases reported including the present case (Table I).

\section{CASE REPORT}

A 29-year-old male presented with diminished hearing on right side, vertigo and loss of taste for five months. He had recurrent aspirations and change of voice for the past two months and unsteadiness of gait for the last month. He also complained of occasional headache. On examination, his higher mental functions were normal. He had a right lower motor neuron type of facial palsy (House-Brackmann grade II), right palatal palsy and nystagmus. There was loss of taste on the right half of the tongue and severe sensory neural hearing loss on the right side. Due to features of seventh and eighth cranial nerve involvement and cerebellar signs, a diagnosis of cerebellopontine (CP) angle tumor was made and MRI was performed. 
Table I: Primary Cerebellopontine Angle Melanoma - Cases Reported Till Date

\begin{tabular}{|c|c|c|c|}
\hline No & Author & Published in & \\
\hline 1. & Bailey P & Intracranial tumors, 1948 & Diagnosed at Autopsy \\
\hline 2. & Bjorkesten G & Acta Psychol 1949 & Diagnosed at Autopsy \\
\hline 3. & Albertengo JB & An Cir 1951 & \\
\hline 4. & Bachtiarow WA & SS Korsako, 1953 & Diagnosed at Autopsy \\
\hline 5. & Terao H & Brain Nerve 1968 & \\
\hline 6. & Narayan RK & Neurosurgery 1981 & $32 \mathrm{yr} M$ \\
\hline 7. & Adam P & J Radiol 1986 & \\
\hline 8. & Braga FM & Arq Neuropsiquiatr $1989 \mathrm{Dec}$ & $72 \mathrm{yr} F$ \\
\hline 9. & Vasdez A & J Neuroradiol. 1990 & \\
\hline 10. & Kamada M & Progress in Computed Imaging, 2000 & 20 yr F \\
\hline 11. & Whinney D & Otology \& Neurotology: 2001 Mar & $29 \mathrm{yr} \mathrm{F}$ \\
\hline 12. & Desai K & Neurol India. 2001 Jun & $17 \mathrm{yr} F$ \\
\hline 13. & Khan P & Skull Base. 2003 Aug & $26 \mathrm{yr} F$ \\
\hline 14. & Oluigbo & Neurosurgery. 2006 Dec & 75 yr M \\
\hline 15. & Piedra MP & Neurosurgery. 2006 Jul & $49 \mathrm{yr} \mathrm{M}$ \\
\hline 16. & Brackmann DE & Otol Neurotol. 2007 Jun & \\
\hline 17. & Bhandari L & & $29 \mathrm{yr} \mathrm{M}$ \\
\hline
\end{tabular}

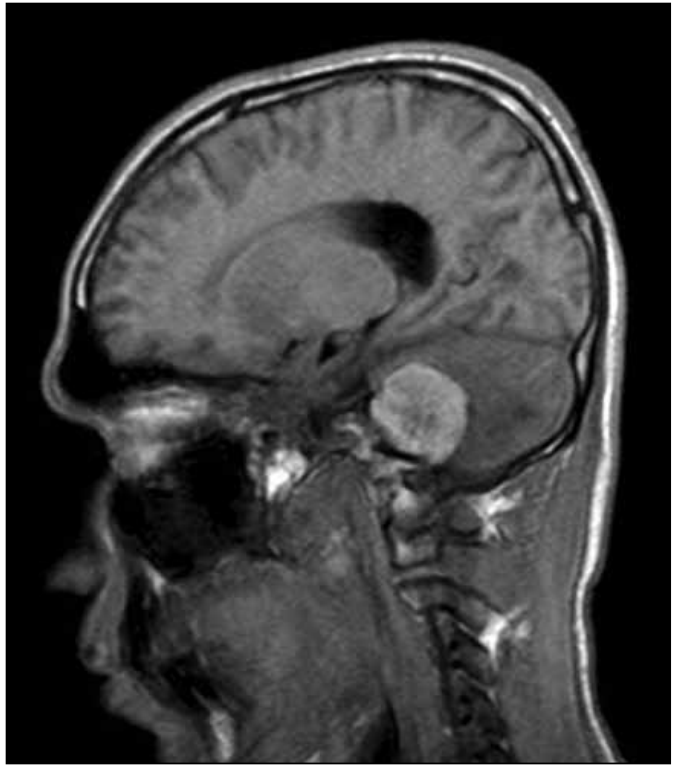

Figure 1: Preoperative MRI T1 weighted image showing hyperintense lesion at the cerebellopontine angle.

Magnetic Resonance Imaging (MRI) revealed a hypointense lesion in the right cerebellopontine cistern on T2-weighted images that was hyperintense on T1-weighted images (Figures 1, 2). The lesion showed minimal enhancement after contrast infusion. Magnetic Resonance Spectroscopy (MRS) demonstrated minimal increase in the choline/NAA ratio and significant elevation of lactate. The possibility of a benign melanin tumor was offered by the radiologist. However, due to the clinical picture we presumed the diagnosis to be either a malignant melanoma or a melanotic schwannoma.

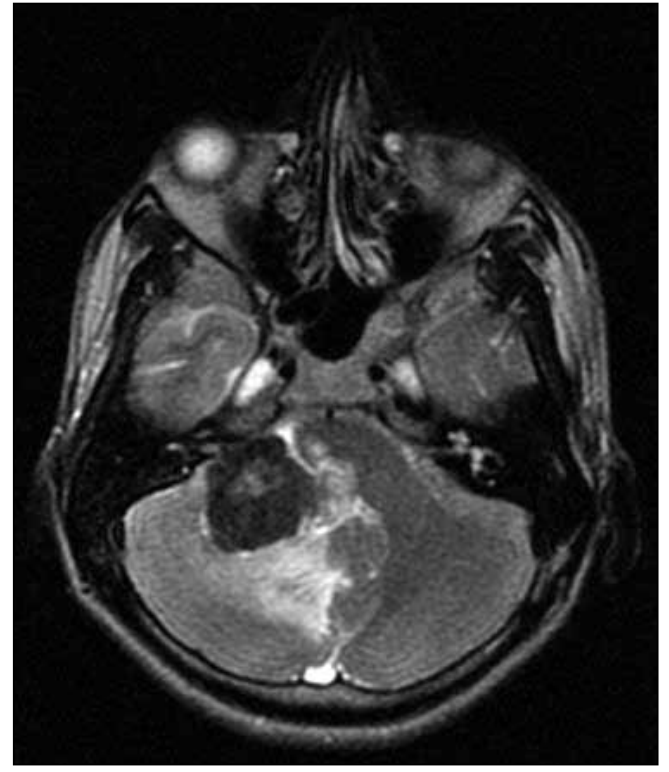

Figure 2: Preoperative MRI: T2 weighted image showing hypointense lesion at the right cerebellopontine cistern.

After preoperative work up, the patient was scheduled for right suboccipital craniectomy. Intraoperatively, the lesion was found to be firm and tough. It was not easily removed either with suction or CUSA. The lesion had to be cut and removed using cutting loupes. The bulk of the tumor was removed, leaving behind a margin of the tumor close to the brainstem (Figures 3, 4, 5).

Microscopic examination revealed a cellular neoplasia composed of large cells with vesicular nuclei and prominent 


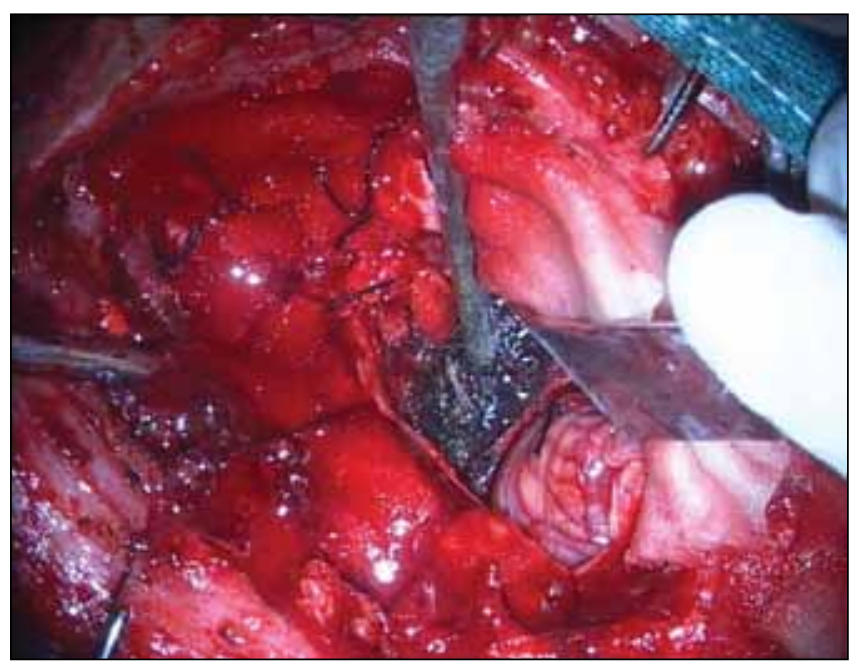

Figure 3: Intraoperative image showing the black colored tumor at the cerebellopontine angle.

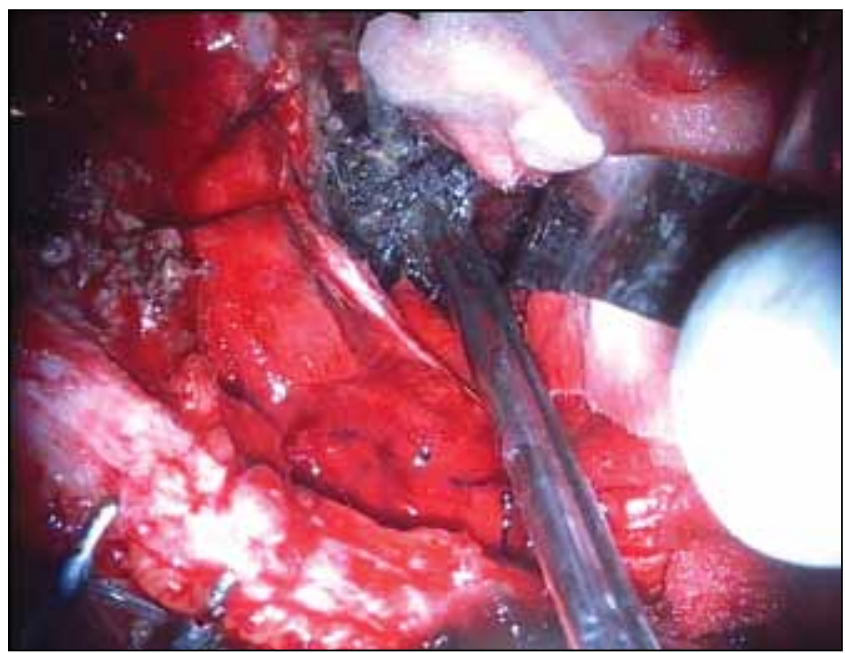

Figure 4: Intraoperative image showing resection of the tumor.

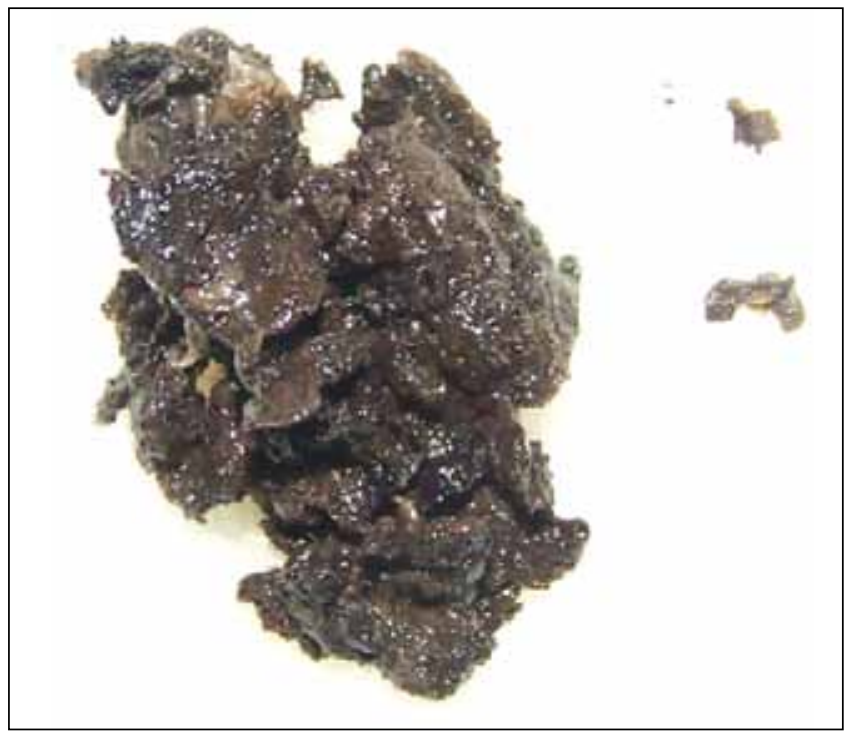

Figure 5: Resected specimen. nucleoli. Several cells showed dense intra-cytoplasmic deposits of melanin pigment. The mitotic rate was high, about 7/10 HPF and focal areas of necrosis were seen (Figures $6,7)$. Thus a diagnosis of malignant melanoma was made. A thorough search of the primary consisting of dermatological evaluation, ophthalmological evaluation, X-ray of the chest and ultrasonography of abdomen was fruitless. We therefore concluded the lesion to be primary melanoma of the cerebellopontine angle.

The immediate postoperative stage was uneventful. The patient was given adjuvant radiotherapy of 5220 cGy over 29 cycles. At two-month follow up the patient remained asymptomatic but follow up Computed Axial Tomography (CAT) showed the presence of tumor remnant (Figure 8). After ten months, the patient presented with weakness in both lower limbs. MRI showed residual tumor and multiple spinal

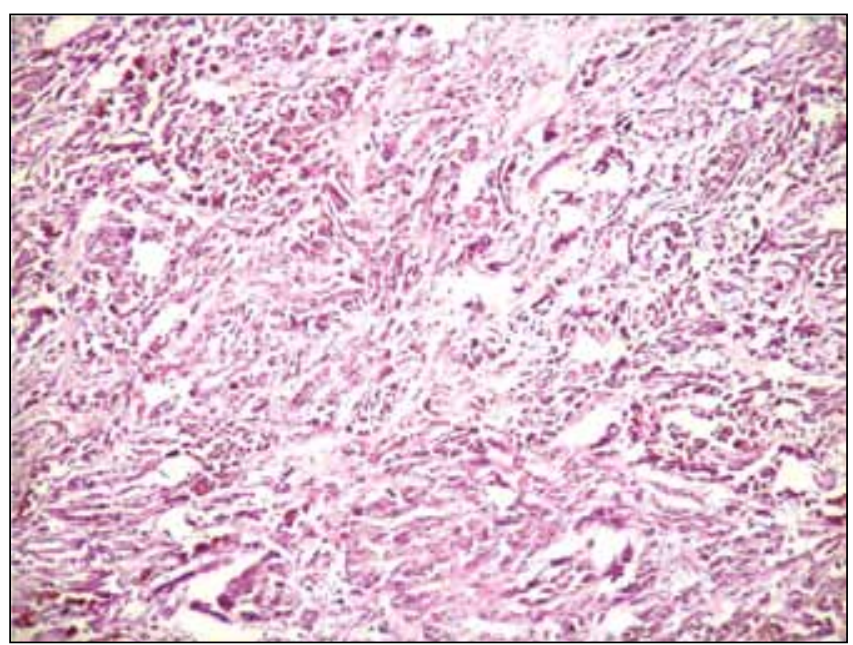

Figure 6: Microphotograph showing the arrangement of pigment laden tumor cells in loose nests and short fasicles (H\&E X 100).

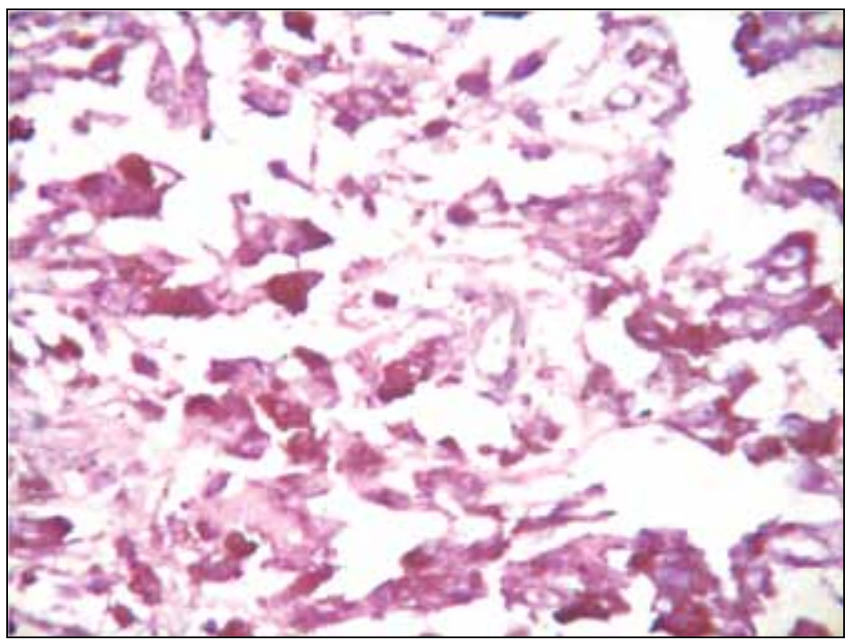

Figure 7: Large, pleomorphic tumor cells with prominent eosinophilic nucleoli and intracytoplasmic dark brown pigment (H\&E X 400). 


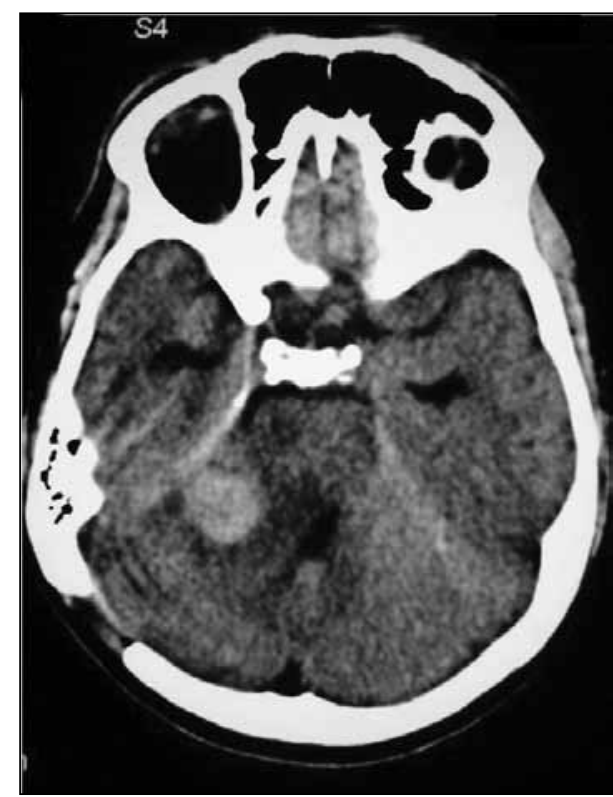

Figure 8: Postoperative CT after 2 months showing residual tumor.

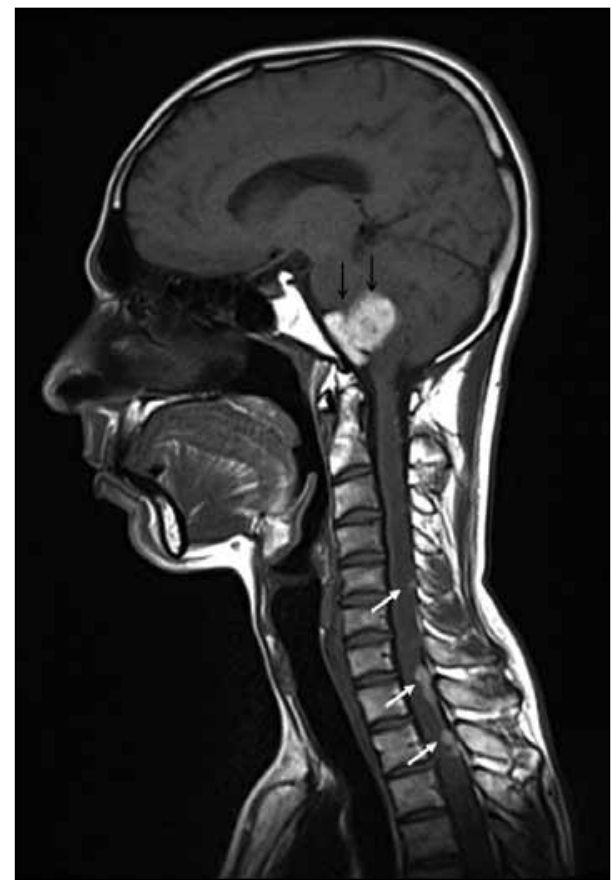

Figure 9: Postoperative MRI after 12 months showing residual lesion (Black arrows) and multiple spinal metastasis (White arrows).

metastases (Figure 9). Spinal radiation was given which lead to some improvement in motor function of the lower limbs. However the patient succumbed to his illness one year after diagnosis.

\section{DISCUSSION}

Leptomeningeal melanocytes are derived from the neural crest during early embryonic development. Melanocytic melanin is similar to skin melanin and different from neuromelanin, which is found exclusively in neurons. The largest concentration of melanocytes is on the piamater surrounding the medulla and high cervical cord (1), and this may reflect the common location of melanocytomas.

Some authors have proposed that dural melanomas may have a possible origin from leptomeningeal deposits where the leptomeninges penetrate into the dura (4). Alternately, heterotopic tissues have been described in dura mater and it is possible for a melanoma to arise from a heterotopic mass of melanocyte producing neural crest cells (9).

\section{Pathology:}

Depending on the biological behavior, Melanocytomas are classified into:

1. Well-differentiated Melanocytoma: These are the benign type, containing variably pigmented melanocytic cells arranged in tight nests, sheets, or fascicles. Nuclei are regular, often with small, eosinophilic nucleoli. Mitotic rates range from zero to one per 10 high-power fields (HPF) and MIB-1 staining is low $(<1-2 \%)$. They tend to occur in the spinal canal and are unlikely to recur after excision.

2. Malignant Melanoma: These lie at the other end of spectrum and are the most malignant type. They consist of larger, cytologically atypical, pigmented tumor cells with bizarre, pleomorphic nuclei growing in loose nests or sheets, often with CNS invasion or necrosis. They have high mitotic rates (about 5.7/10 HPF) and high MIB-1 labeling index (about 8.1\%). They have a high propensity to recur and a poor prognosis.

3. Intermediate Grade Melanocytoma: the intermediate grade melanomas are difficult to define. The histopathological features of intermediate-grade melanocytic tumors lie in between that of melanocytoma and melanoma. They have sheet-like growth patterns, microscopic CNS invasion, and occasional mitoses. MIB-1 staining ranges from $1 \%$ to $4 \%$. There have also been 5 reported cases of intermediate grade melanomas turning into frank malignant melanoma. It is therefore likely that these three lesions are the spectrum of a same disease rather than three different clinical entities.

All three types are immunoreactive for HMB-45 and S-100 protein and negative for epithelial membrane antigen (3).

\section{Clinical Presentation:}

Melanomas of the CNS have a peak at the $4^{\text {th }}-5^{\text {th }}$ decades and have a male preponderance. Like all melanomas they are less common in blacks (2). Gibson in 1957 classified primary leptomeningeal melanoma into two groups (9):

Group A or diffuse variety is the rarer one, and more common in adults than in children. In children they are associated with neurocutaneous melanosis (5). Clinically they present with features of raised intracranial pressure and are difficult to 
pick up on CT/MRI. The antemortem diagnosis is notoriously difficult and it mimics a variety of conditions like lymphoma, leukemia, metastatic carcinoma, subacute meningitis, viral encephalitis, and idiopathic hypertrophic cranial pachymeningitis (12) .

Group B or the discrete variety is the commoner of the two, and presents with features of raised intracranial tension with focal signs and meningism (2). These cases are easily picked up on CAT/MRI. While they are usually diagnosed as an intracranial space occupying lesion, the exact pathology and malignant nature are difficult to assess preoperatively. They have a relatively better prognosis.

\section{Diagnosis:}

The typical CAT finding is a contrast enhancing hyperdense mass. On MRI, the classical finding is of a hyperintense lesion on T1 and hypointense lesion on T2. There have been few cases reported with hypointense $\mathrm{T} 1$ and iso-high intese $\mathrm{T} 2$ WI. These variations are thought to be due to the degree of paramagnetic effect of stable free radicals in melanin and intratumoral hemorrhage (6). Although CAT/MRI point towards the presence of melanin, the exact pathology cannot be determined. It is also difficult to determine whether the lesion is benign or malignant. The only clue on imaging is leptomeningeal dissemination, which is difficult to pick up on CAT/ MRI. There is not enough data to suggest any advantage of Magnetic Resonance Spectroscopy (MRS). MRS in our case demonstrated only a minimal increase in choline/ NAA ratio and pointed towards a benign disease.

The final diagnosis is made by the pathologist, based on the mitotic figures, nuclear atypia and MIB 1 index. If the lesion is at the $C P$ angle, like in our case, it must be differentiated from melanotic schwannoma. Melanotic schwannomas are well circumscribed, partly encapsulated lesions characterized by polygonal and vesicular cells with grooved nuclei. These cells also contain abundant melanin pigment.

Immuno-histochemical markers used are S100 (a protein expressed in cells of neural crest origin), HMB 45 (detects melanosomes) and Melan. Among these S100 has high sensitivity while HMB 45 has high specificity. Since melanocytomas of all grades as well as melanin containing tumors like melanotic schwannomas react positively, they help little to differentiate between these pathological types. $(12,6)$

\section{Management:}

Surgical excision is the primary mode of treatment. Total excision is better than subtotal excision, not only for melanomas but also in case of melanotic schwannoma and intermediate grade melanoma. $(2,3,6,11,4)$. Total excision anyhow would be impeded by involvement of lower cranial nerves and major vessels.

Use of adjuvant therapies do not share such a similar consensus. Traditionally Chemotherapy and Radiotherapy(RT) had no role in primary CNS melanomas, while some chemothera- peutic agents like Temozolamide and decarbazine were used in metastatic melanoma. (7). RT using fractionized irradiation in high doses has improved response rates for melanomas (10). Gamma knife radiotherapy has shown some benefit in intermediate grade melanocytomas. (4) Among chemotherapeutic agents, DTIC when used along with 1-(4-amino-2methyl-5-pyrimidinyl) methyl-3-(2-chloroethyl)-3-nitrosourea hydrochloride (ACNU), and vincristine with OK 432 (picibanil) has shown promising results. (10).

\section{Prognosis:}

Melanomas are notorious for their dismal prognosis. The average survival figures for various melanocytic lesions are shown in Table II.

Table II: Average Survival of Various Melanotic Lesions at the Cerebellopontine Angle

\begin{tabular}{|l|l|}
\hline Melanotic Lesion & Mean Survival \\
\hline Metastatic melanoma & $<100$ days \\
Diffuse Melanoma & 6.7 months \\
\hline Solitary melanoma & \\
1. Total removal & 19.5 months \\
2. Subtotal removal & 9.3 months \\
3. Not operated & 3.4 months
\end{tabular}

The factors determining prognosis are, type of lesion, Involvement of lepromeninges, Amount of tumor excised and MIB 1 index. Among these the most significant one is MIB 1 index.

\section{CONCLUSION}

After a review of literature we offer the following classification for Melanotic tumors of CNS:

1. Primary Melanotic lesions: these are derived from melanocytes leptomeninges and rarely from the dura. Primary melanotic lesions may arise either de novo or in the backdrop of neurocutaneous melanosis

a. De novo: Depending upon their tumor behavior they are further classified as

$\begin{array}{cl}\text { i. } & \text { Well differentiated melanocytoma } \\ \text { ii. } & \text { Intermediate grade melanocytoma } \\ \text { iii. } & \text { Primary Malignant melanoma }\end{array}$

b. Neurocutaneous melanosis: It is a rare congenital syndrome characterized by the presence of large or multiple congenital melanocytic nevi and benign or malignant pigment cell tumors of the leptomeninges. The syndrome is thought to represent an error in the morphogenesis of the embryonal neuroectoderm which leads to proliferation of melanin-producing cells in both the skin and the leptomeninges. (5)

2. Other primary tumors of CNS with melanotic elements: These tumors arise from non-melanoma cells of CNS. They acquire melanin. 

a. Meningioma
b. Medulloblastoma
c. Astrocytoma
d. Melanotic schwannoma
e. Pituitary tumors
f. Choroid plexus papilloma

3. Secondary malignant melanoma: We prefer to put secondary melanoma separately as its etiology, tumor biology, clinical features and prognosis are quite different from primary melanocytomas.

Thus histopathological observation of anaplastic cells with melanosomes does not point towards the cell of origin. Nor do the present day immuno histo-chemical markers make such distinction. Whether or not such a distinction is made, the prognosis is abysmal. The clinical pathway of a CP angle melanotic lesion is depicted in Figure 10.

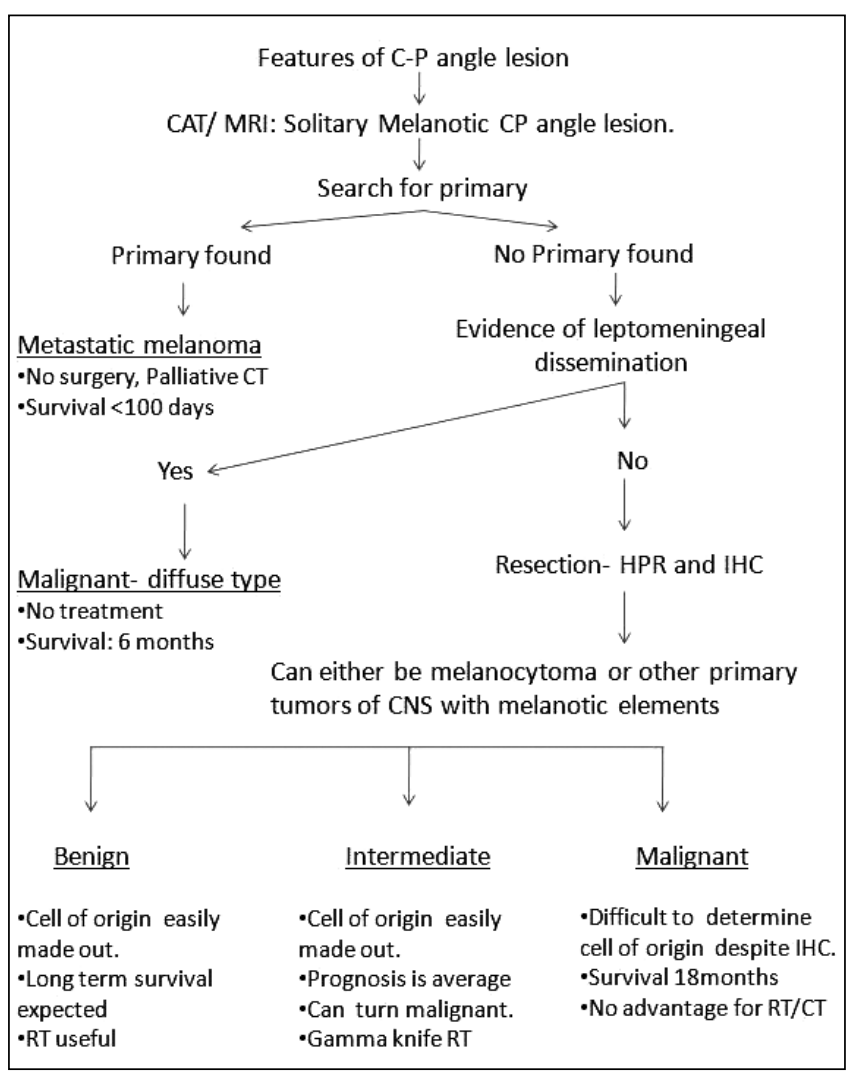

Figure 10: Present day diagnostic pathway for a melanotic CP angle Lesion. CP: Cerebellopontine, CAT: Computed axial tomography, MRI: Magnetic resonance imaging, CT: Chemotherapy, HPE: Histopathological Examination, IHC: Immunohistochemistry, RT: Radiotherapy.

\section{REFERENCES}

1. Arbelaez A, Castillo $M$, Armao MD: Imaging features of intraventricular melanoma. AJNR Am J Neuroradiol 20: 691-693, 1999

2. Rodriguez y Baena R, Gaetani P, Danova M, Bosi F, Zappoli F: Primary Solitary intracranial melanoma: Case report and review of literature. Surg Neurol 38: 26- 37, 1992

3. Brat DJ, Giannini C, Scheithauer BW, Burger PC: Primary melanocytic neoplasm of the central nervous system. Am J Surg Pathol 23:745-754, 1999

4. Hamasaki O, Nakahara T, Sakamoto S, Kutsuna M, Sakoda K: Intracranial meningeal Melanocytoma - Case report. Neurol Med Chir (Tokyo) 42: 504-509, 2002

5. Kadonaga J, Frieden I: Neurocutaneous melanosis: Definition and review of the literature. Acad Dermatol 24:747-755, 1991

6. Kashiwagi N, Hirabuki N, Morino H, Taki T, Yoshida W, Nakamura $\mathrm{H}$ : Primary solitary Intracranial melanoma in sylvian fissure: MR demonstration. Eur Radiol 12: S7-10, 2002

7. Khan P, Shelton C, Townsend J, Jensen R: Primary Malignant Cerebellopontine angle melanoma presenting as a presumed meningioma: Case report and review of the literature. Skull base 13:159-166, 2003

8. Liu XW, Chi ZF, Zhao XE, Wu W: The clinical features and meningeal histochemistry of meningeal malignant melanosis. Chin Med J 121:2458-2460, 2008

9. Narayan RK, Rosner MJ, Povlishock JT, Girevendulis A, Becker DP: Primary Durla Melanoma: A clinical and morphological study. Neurosurgery 9:710-716, 1981

10. Oh JY, Joo W, Rha HK, Kim YW: Primary occipital malinant melanoma. J Korean Neurosurg Soc 41: 39-42, 2007

11. Piedra MP, Scheithauer BW, Driscoll CL, Link MJ: Primary Melanocytic tumor of the cerebello-pontine angle mimicking a vestibular schwannoma: Case report. Neurosurgery 58: 206-207, 2006

12. Pirini MG, Mascalchi $M$, Salvi $F$, Tassinari $C A$, Zanella $L$, Bacchini P, Bertoni F, D’Errico A, Corti B, Grigioni WF: Primary diffuse meningeal melanomatosis: Radiologic-pathologic correlation. AJNR Am J Neuroradiol 24:115-118, 2003

13. Schuchter LM, Haluska F, Fraker D, Elenitsas R: Skin: Malignant melanoma In: Abeloff MD (ed) Clinical Oncology. New York: Churchill Livingstone, 2000:1326-132

14. Whinney D, Kitchen N, Revesz T, Brookes G: Primary malignant melanoma of the cerebellopontine angle. Otol Neurotol 22: 218-222, 2001 